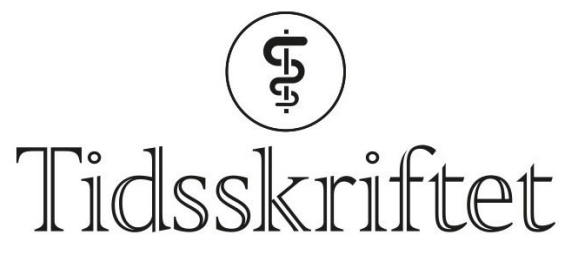

DEN NORSKE LEGEFORENING

\title{
NK-celler kan bidra til immuntoleranse
}

FRA ANDRE TIDSSKRIFTER

HAAKON B. BENESTAD

Universitetet i Oslo

Visse naturlige dreperceller undertrykker immunresponser og kan bidra til utvikling av mors toleranse overfor fosteret.

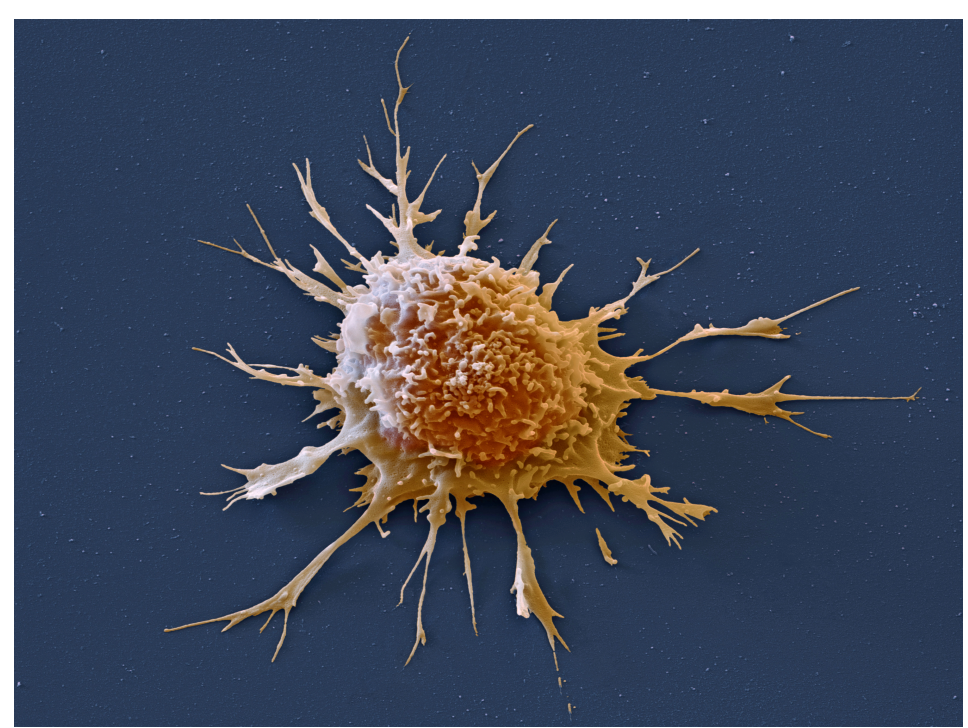

Illustrasjonsfoto: Science Photo Library

Det er uklart hvordan gravide blir tolerante overfor fosteret, som jo har paternelle antigener. Kan NK-celler - naturlige dreperceller - bidra til denne immuntoleransen? I en studie med blodceller fra gravide kvinner kunne NK-celler med Tim-3-reseptor på overflaten produsere antiinflammatoriske cytokiner som TGF- $\beta 1$, IL-10 og IL-4, mens proinflammatoriske cytokiner, som TNF- $\alpha$, ble nedregulert (1). Hos kvinner med normalt svangerskap økte mengden av Tim-3-reseptor på NK-celler i første trimester, men mindre hos kvinner som spontanaborterte. Den sistnevnte gruppen hadde også lavere blodkonsentrasjon av Tim-3-liganden Gal-g. Tim-3-NK-cellene hos disse kvinnene medførte også nedsatt danning av regulerende T-celler $\left(\mathrm{T}_{\text {reg }}\right)$, som er viktige toleranseinduserende celler.

I en musemodell med høy abortfrekvens reduserte Gal-g-injeksjon tap av fostre, mens blokkering av Tim-3-reseptoren ga større tap av fostre. 
- Det er mulig at Tim-3-positive NK-celler kan bli en interessant biomarkør hos kvinner med gjentatte spontanaborter, sier Anne Spurkland, som er immunolog og professor ved Institutt for medisinske basalfag ved Universitetet i Oslo. Hun påpeker at resultatene må verifiseres i flere studier.

- Tim-3-reseptoren er også høyt uttrykt på «slitne» T-celler som har vært aktivert i en uke eller mer, og er nylig tatt med som et av flere mulige mål for kreftimmunterapi. Reseptoren ser ut til å være av mer generell betydning for å begrense langvarige immunologiske reaksjoner og sikre toleranse mot eget vev ved kroniske infeksjoner, sier hun.

\section{LITTERATUR:}

1. Li Y, Zhang J, Zhang D et al. Tim-3 signaling in peripheral NK cells promotes maternal-fetal immune tolerance and alleviates pregnancy loss. Sci Signal 2017; 10: eaah4323. [PubMed][CrossRef]

Publisert: 8. januar 2018. Tidsskr Nor Legeforen. DOI: 10.4045/tidsskr.17.0954

(C) Tidsskrift for Den norske legeforening 2020. Lastet ned fra tidsskriftet.no 